\title{
General description of the smart city governance system component "Smart Education" on the experience of Uzbekistan
}

\section{Said-Amirkhan MAKHMUDOV ${ }^{1}$}

National university of Uzbekistan

\section{ARTICLE INFO \\ Article history: \\ Received September 2020 \\ Received in revised form 15 \\ September 2020 \\ Accepted 25 September \\ 2020 \\ Available online \\ 1 October 2020}

Keywords:
Smart controlling system
Smart education
Component
World experience
Distance learning
Innovation

\begin{abstract}
The article discusses the implementation process of Smart City governance system in Uzbekistan. The research found several components of smart governance. In particular, Smart Education System component have discussed in details on the experience of Uzbekistan. Important tasks for today in the context of organization modern education system and their alternative solutions were outlined. The current state of the education system and their transformation to national standards based on international experience were assessed. The author focused on the fundamental foundations of significant results achieved in the field of integrated education over the years of independence, and emphasizes the importance of the system in implementing innovative changes based on practical examples. Achievements in the implementation of modern education have described in terms of the attributes of Smart education. Also, measures for the introduction of smart education in Uzbekistan were analyzed on the basis of real statistics and general summaries were presented
\end{abstract}

2181-1415/@ 2020 in Science LLC.

This is an open access article under the Attribution 4.0 International (CC BY 4.0) license (https://creativecommons.org/licenses/by/4.0/deed.ru)

\section{Aqlli shahar boshqaruvi tizimi komponenti - "Aqlli Ta'lim"ning umumiy tavsifi o'zbekiston tajribasi misolida АННОТАЦИЯ}

\author{
Калит сўзлар: \\ Aqli boshqaruv tizimi \\ Aqli ta'lim \\ Komponent \\ Dunyo tajribasi \\ Masofaviy ta'lim \\ Innovatsiya
}

Maqolada Aqlli shahar boshqaruvining O'zbekistonga tadbiq qilish jarayonlari haqida so'z yuritiladi. Tadqiqot natijalariga ko'ra, Aqlli boshqaruvning bir qancha komponentlari aniqlandi. Xususan, Aqlli ta'lim tizimi komponenti O'zbekiston tajribasi misolida batafsil ko'rib chiqilgan. Bugungi kunda zamonaviy

\footnotetext{
${ }^{1}$ Teacher of the history of Uzbekistan, National university of Uzbekistan Tashkent, Uzbekistan e-mail: saidamirxon.mahmudov.1994@mail.ru
} 
ta'lim tizimini tashkil etishdagi dolzarb vazifalar hamda ularning muqobil yechimlari xususida muhim vazifalar aniqlangan. Shuningdek, dunyo tajribasi asosida milliy andozalarga moslashtirib kelinayotgan ta'lim tizimlari va ularning joriy holatiga urg'u berib o'tilgan. Muallif mustaqillik yillarida integatsion ta'lim sohasida qo'lga kiritilgan salmoqli natijalarning fundamental asoslari haqida so'z yuritib, tizimning innovatsion o'zgarishlarni joriy etishdagi ahamiyatiga amaliy misollar orqali to'xtalib o'tgan. Zamonaviy ta'limni joriy etishda qo'lga kiritilayotgan yutuqlar Aqlli ta'lim tizimi atributlari kesimida tavsiflab berilgan. Shuningdek, O'zbekistonda Aqlli ta'lim tizimini joriy etish yo'lidagi chora-tadbirlar real statistik ma'lumotlar asosida tahlil qilinib, yakunda umumiy xulosalar taqdim etilgan.

\title{
Общее описание компонента системы управления умным городом «умное образование» на примере опыта узбекистана
}

\author{
Ключевые слова: \\ Умная система управления \\ Умное образование \\ Компонент \\ Мировой опыт \\ Дистанционное обучение \\ Инновация
}

\begin{abstract}
АННОТАЦИЯ
В статье рассматривается процесс внедрения Умное управление в Узбекистане. Исследование обнаружило несколько компонентов разумного управления. В частности, компонент Системы умного образования подробно обсуждается в опыте Узбекистана. Обозначены важные задачи сегодняшнего дня в организации современной системы образования и их альтернативные решения. Было дана оценка текущему состоянию системы образования и их адаптации к национальным стандартам на основе мирового опыта. Автор акцентирует внимание на фундаментальных основах значительных результатов, достигнутых в сфере интегрированного образования за годы независимости, и подчеркивает важность системы в реализации инновационных изменений на практических примерах. Достижения внедрения современного образования описываются с точки зрения атрибутов «Умное образование». Также были проанализированы меры по внедрению умного образования в Узбекистане на основе реальной статистики и представлены общие выводы.
\end{abstract}

Today's innovative development has already covered all spheres of society. In this regard, the management sector also should be noted. As you know, today "Strategy of Action" became basis of all important reforms. At the same time, based on foreign experience resolution of the Cabinet of Ministers of the Republic of Uzbekistan No. RCM48 has adopted on January 18, 2019 about "The Concept of the implementation of smart urban technologies" and the Plans for 2019-2021 years "Practical measures for the implementation of the Concept of implementation of smart urban technologies" [1]. 
If we look at foreign literature and magazines, we could see how importance of "smart cities" and their relevance for today's development.

For instance, article of M. Batty, K.W. Axhausen, F. Giannotti, A. Pozdnoukhov, A. Bazzani, M. Wachowicz, G. Ouzounis, and Y. Portugal, which published on December 5, 2012 in The European Physical Journal special topics (Smart Cities of the Future) they have mentioned about emergence of smart cities - "There are powerful networks in the world today, including: all transportation systems, utilities, smart metering, local weather, pollution levels and waste, destruction, land planning, energy saving and use of construction technologies, the list of health information systems is endless. The point is, we urgently need a map of the region so that we can combine these different activities [2]. In short, the main need for the emergence of a smart city is to create a systematic and useful solution aganist growing and expanding systemic problems. It consists of striving from chaos to synergy.

According to the study by University of North Texas scientists Saraju P. Mohanty, Uma Chopalli and Elias Kougianos, global population growth in recent years and by 2050 more than $70 \%$ of the population could live in cities. It means that $80 \%$ of greenhouse gases would be concentrate in cities. This assumption, which is becoming increasingly realistic, is being taken as a factor by scientists, who point out that "smart cities" as a unique strategy for overcoming the problems that may arise in the process of rapid urbanization. In this regard, a number of requirements have been developed by the International Organization for Standardization (ISO), which believes that these standards play an important role in ensuring the safety and quality life conditions of a smart city [3]. The world experience has considered different and comprehensive views on the studying issue. Another proof is ATIS. ATIS is a complex of large companies in the field of information and communication technologies (ICT) to address common, important priorities, headquartered in the United States. The main tasks of ATIS are to reach agreements on problem solving and development of new business opportunities, to have a long-term, strategic vision for the development of the process of industrial transformation or to create a platform for cooperation with other states' industries and stimulate to innovation [4].

Smart Cities Technology Roadmap by ATIS has published in the U.S. in 2017, and mentioned completely about details components of the Smart cities [5].

The RCM-48, adopted by the Cabinet of Ministers of the Republic of Uzbekistan, is a legal project which designed to make extensive use of foreign experience and to keep pace with the times in accordance with the governance standards of Uzbekistan. This legal document identifies a number of components as the main directions of implementation of "Smart city" technology projects in Uzbekistan.

Undoubtedly, the most important of these components is the "Smart education" system. Transforming education into an intelligent format is an objective concept that requires an understanding of educational institutions equipped with the latest technology and in-depth approach to this issue based on the capabilities of educational institutions. Education has a special place in the system of "Smart management". This is because the development of the state cannot be imagined without quality and modern education, and adequately qualified personnel. Historically, education has been seen as an urgent issue on 
the agenda. The Smart Education system in smart cities is based on the following arguments.

First, an artificial intelligence based education system with the opportunity to test students;

This includes greater involvement of informational technologies in education and increasing the level of speed, high-quality education through artificial intelligence. Each educational institution will have its own quality online educational platform, which will train future staff using a special system. Institutions of higher education have their own experimental programs in this case. Especially today, part-time and evening education became fully online. For using, need to access the official website of any university and register on the distance education portal with a special login-password.

Second, the system of intellectual identification of the individual;

This factor can be compared to the legacy of the great commander, statesman Amir Temur in the form of a didactic novel "Temur Tuzuklari". Context about ministerial selection system. According to the summary of the ministerial selection system, firstly Amir Temur focused on the candidate's lineage, and then on his intelligence [6]. In other words, the intellectual level of the candidate was important.

In the field of educational management, anumber of practical experiments $\mathrm{w}$ being conducted in Uzbekistan, taking into account that the system of intellectual identification of the individual will contribute to the further development of mature and in-demand personnel. In particular, the State Testing Center of the Republic of Uzbekistan has studied the world experience in IQ tests during recent years. Today, the State Testing Center has developed a "Progressive Matrix"* customized test system that determines the level of intellectual development of the individuals on the basis of the John Raven method [7].

As of January 2019, their approbation has been held for free. Given that the tests mainly conducted among students of higher and secondary special educational institutions. It helps for candidates at the next stage of education, candidates could draw the necessary conclusions about competition in the labor market. A similar experience is traditionally held every year between the faculties of foreign languages of state universities. That is, graduate students take the CEFR* exam and find out their level of English proficiency. This, in turn, will have a positive impact on the candidate's future career [8]

Third, the gradual establishment and improvement of the system of distance learning and e-learning;

Fundamental efforts have been made in this direction throughout the country. This is an important factor during the implementation of foreign models on school education or in the transition from the rating system of public universities and institutes to credit system. The revival of forms of education, such as part-time and evening education, have opportunity for increasing reforms in this area. At the same time, the Ministry of Public

\footnotetext{
* Progressive Matrices - Ta'lim muassasalarida tashkil etiladigan yoza test turi bo'lib, 5 yoshdan tortib keksa yoshdagi fuqarolarning inteletual, mantiqiy fikrlash hamda bilim darajasini aniqlashda foydalainadi. Qarang : https://ru.qwe.wiki/wiki/Raven\%27s Progressive Matrices.

* CEFR - (Common European Framework of Reference for Languages) - The Common European Framework of Reference for Languages: Learning, Teaching, Assessment, abbreviated in English as CEFR or CEF or CEFRL, is a guideline used to describe achievements of learners of foreign languages across Europe and, increasingly, in other countries. Look: https://en.wikipedia.org/wiki/Common European Framework of Reference for Languages
} 
Education, the Ministry of Higher and Secondary Special Education has created special electronic portals, which are used not only by teachers and by students as well.

Including dist.edu.uz - Distance learning portal, tube.edu.uz - distance learning media portal, eduuz_online - official channel of distance learning at telegram network, audiobook.edu.uz - distance learning e-book database, mk.bimm.uz - a platform for distance learning courses for professors and teachers of higher education institutions, as well as remote portals of higher education institutions in the regions, particular in Tashkent [8].

The websites dtm.uz, ziyonet.uz, bilim.uz, bilimdon.uz, ilm.uz, student.uz, study.uz have also taken their place in the distance educational system.

Fourth, the introduction of e-journals covering all stages of education;

According to the world experience, there are various scientific bases for receiving, processing and exchanging electronic information above the world. These include Scopus, Q1, Q2 indexes, Google Scholar, Resarch Gate, e-Library, RINS and etc [9].

While these databases and indices remain the status of researchers, they determine the ranking of universities in which they have been operating. The introduction of the system of state-registered journals which meet international standards would allow for greater dissemination of scientific potential.

Fifth, online and offline learning integration systems;

Since spreading of the SARS Covid-19 virus from People's Republic of China in December 2019, which has been recognized as a pandemic by the World Health Organization, has dealt a serious blow not only to the economy but also to the traditional education system. However, due to the widespread introduction of modern information technologies and the extraordinary flexibility of the staff, we have once again learned the need to organize education in any conditions for today and what to do about it in the future. As a result of introduction new systems for organizing classes online and offline in the smart education system has become an important task. Therefore, new 2020-2021 academic year decided to organize both traditional and distance (hybrid) way [10].

Due to the pandemic, the National University of Uzbekistan has re-launched the distance learning portal - http://ettt.nuu.uz/ for the the second term of 2019-2020 academic year [11]. For the 2020-2021 academic year, launched completely new type of platform webdars.uz [12].

In addition, professors organize lectures and workshops using video communication applications such as Zoom, Google Meeting, IMO conference, Discord, as well as Telegram messenger.

Sixth, the development of adaptive and mobile learning technologies;

Let's look at this priority with a few practical examples. In particular, in school education Academy (https://uz.khanacademy.org), Edu Market (https://edumarket.uz), Eduportal (http://eduportal.uz), Kitob.uz (http: // Educational resources such as www.kitob.uz), Online School (http://www.online-maktab.uz), Maktab.uzedu.uz (http://maktab.uzedu.uz) and Utube.uz (https://utube.uz) have been created all necessary conditions for using websites[13]. 
In higher education, teachers and students have developed the skills of using by Moodle system*, online lectures on various platforms like Zoom, Discord, and creating video lessons through Bandicam, OBS-studio, Camtastudio [14].

The deep integration of technology into the education system will be an important factor on improving its quality in the future. After all, in a smart city smart learning environment must be fully formed. Because smart city citizens required to have high intelligence. According to the official video "Smartest country comparison" posted on the YouTube channel "Reigarw comparisons", as of January 2019, the average IQ of the population of the Republic of Uzbekistan was 87 points, and the world ranks 75-85th among nearly 200 states compared to. The top three are not the countries like United States and the Russian Federation, but Japan, Republic of Korea and Singapore, which have already moved to a "Smart city" system[15]. Knowledge in the field of informational technologies is crucial. Today, every aspect of society and state life has managed and updated through informational technologies. In the future, new e-learning institutions will be formed in the city administration. Concepts such as IT Park, Digital Park, Hitech camp are could be example for that.

Following arguments have noted as the summary:

- Smart education system is the key component of the smart management system;

- The introduction of test systems for determining the intellectual ability of the individual will help to raise the quality of personnel in the future. It will effect to the level of world standards. Uzbek national personnel would hire not only in the domestic labor market but also abroad;

- Adaptation of the distance education system to national standards on the basis of foreign experience, serves as a basis for ensuring the continuity of the education system in all conditions;

- In the context of the pandemic, Uzbekistan has been able to create a unique model in the education system and implement the reforms that have long been expected to be widely implemented;

- The innovative system which created in the smart city plays a significant role on increasing the foreign prestige of the republic, especially in the formation of city's image.

\section{REFERENCES}

1. Resolution of the Cabinet of Ministers of the Republic of Uzbekistan "On approval of the Concept of establishing of smart urban technologies" in the Republic of Uzbekistan No. RCM-48 https://lex.uz/docs/-4171067 (Appendix 2 As amended by Resolution No. 348 of June - National Database of Legislation, 04.06.2020, No. 09/20/348/0716).

2. M. Batty, K.W. Axhausen , F. Giannotti, A. Pozdnoukhov, A. Bazzani, M. Wachowicz, G. Ouzounis, Y. Portugali. Smart cities of the future. The European physical journal special topics Eur. Phys. J. Special Topics 214, 481-518 (2012) (CThe Author(s) 2012. This article is published with open access at Springerlink.com DOI:10.1140/epjst/e2012-01703 5December, 2012.

\footnotetext{
* Moodle system - is a free and open-source learning management system (LMS) written in PHP and distributed under the GNU General Public License. Developed on pedagogical principles, Moodle is used for blended learning, distance education, flipped classroom and other e-learning projects in schools, universities, workplaces and other sectors. Take a look : https://en.wikipedia.org/wiki/Moodle
} 
3. P. Mohanty, Uma Chopalli, Elias Kougianoslar. Everything You wanted to Know about Smart Cities.

4. Google search : What is AITS ? https://www.atis.org/01_about/

5. Smart cities technology roadmap. Alliance for Telecommunications Industry Solutions 1200 G Street, NW, Suite 500 Washington, DC 20005 Copyright (C) 2017 by Alliance for Telecommunications Industry Solutions.

6. Amir Temur's rules. International Foundation of Amir Temur, T.: Sharq, 2005. Translated by Alikhantora Soguni and Habibulla Karomatov. p. 80-82.

7. ru.wikipedia.org/wiki/Тест_Рейвена

8. https://dist.edu.uz/\#bb

9. Wikipedia.org/wiki/Индекс_цитирования_научных_статей

10.https://bmti.uz/ozbekiston-respublikasi-prezidenti-qarori-2019-2020-oquv-yilidaozbekiston-respublikasining-oliy-talim-muassasalariga-oqishga-qabul-qilishning-davlatbuy/yangiliklar/

11.http://ettt.nuu.uz/

12.http://webdars.nuu.uz/

13.Necessary platforms for online school program - https://uzedu.uz/oz/koronavirusxtv-amalga-oshirilayotgan-ishlar

14.Online platforms created in higher education system https://review.uz/uz/post/foydali-karantin-covid-19-pandemiyasi-oliy-talim-tizimini-qandayozgartiradi

15.Smartest counry comparison - $\underline{\mathrm{https}} / \mathrm{/} / \mathrm{www}$. youtube.com/watch?v=46KCbYe6gEA 